\title{
Community And Individual Factors Associated With Maternal And Neonatal Care Practices In Low Resource Settings. A Case Of Zimbabwe
}

\author{
E. Chiwawa, M. Mhlanga, A. Munodawafa, and F. Mukora-Mutseyekwa
}

\begin{abstract}
Neonatal mortality has been increasing in Zimbabwe from 20/1,000 live births between 2000 and 2004 to $29 / 1,000$ live births between 2010 and 2014.Suboptimal newborn care practices are the predisposing factors to neonatal mortality. In Manicaland Province, care seeking behaviours for fever which is the main symptom of majority of infections in children and knowledge levels of danger signs that should cause the mother to take a child immediately to a health facility remains unacceptably lower than the national averages. A cross sectional descriptive and analytic design was carried out to explore the factors associated with the practice of the recommended newborn care practices by women of child bearing age in Mutare District. Health facilities were purposively sampled and participants were systematically sampled. Structured interviews were used to collect data which was analysed in Epi-Info version 7.2. Descriptive and multivariate analysis was performed on data collected from 349 participants. Practice of the five assessed recommended newborn care practices was high. Exclusive breast feeding $(62 \%)$, early initiation of Breast feeding (74\%), good code care $(73 \%)$, care seeking for neonatal illness within $24 \mathrm{hrs}$ of onset of fever $(82 \%)$ and keeping baby warm was at $58 \%$. Statistically significant independent factors associated with the recommended newborn care practices were post-natal stay for more than 72 hours at the clinic $(A O R=0.56 ; 95 \%$ CI: $0.12-0.87$, $\mathrm{p}=0.000)$, and delivery at the health facility $(\mathrm{AOR}=0.43 ; 95 \% \mathrm{CI}$ : $0.21-0.77 ; p=0.000$ ). Cultural practices that impact negatively on neonatal care in Mutare district include; asking for permission to seek treatment for the child when ill, feeding the baby immediately after delivery and applying substances and mixed traditional herbs on the cord stump of the newborn. Improving newborn care outcomes require approaches addressing demand and supply factors to reach communities with correct information on good newborn care.
\end{abstract}

Index Terms - Neonatal Mortality; Neonatal care.

\section{INTRODUCTION}

Despite these accomplishments in the reduction of underfive mortality, there has been slow progress in the reduction of neonatal mortality a key driver of child mortality. It is estimated that four million neonatal deaths occur each year and sixty six percent of these newborn deaths occur in the first week of life [1], [2]. About ninety nine percent of these deaths are concentrated in Sub-Saharan Africa and East Asian Regions were most of the newborns die at home [3], [4].

In Zimbabwe, the Multiple Indicator Cluster Survey [5],

Published on July 10, 2020.

E. Chiwawa, Africa University, Zimbabwe.

(e-mail: chiwawaedhina@gmail.com).

M. Mhlanga, University of Zimbabwe, Zimbabwe.

(corresponding e-mail: profmaxmhlanga7@gmail.com). indicates that the neonatal mortality levels have been on the increase across the successive five-year periods. The neonatal mortality rate was 20 deaths per 1,000 live births between 2000 and 2004; 25 deaths per 1,000 live births between 2005 and 2009; and lastly 29 deaths per 1,000 live births between 2010 and 2014.

Manicaland Province is among the top two populated provinces in the country, coming second after Harare Metropolitan province. Although an improvement has been noted across all areas in the performance of maternal, newborn and child health indicators in the MICS5 compared to the 2010/11 ZDHS performance in Manicaland Province, the achievements are still below the average national coverage with regards to key indicators necessary for neonatal survival. The rates for institutional delivery, skilled attendance at delivery, post-partum stay in health facility for 3 days or more coverage $(72 \%, 72.2 \%$, and $25.5 \%)$ remain still low compared to the national coverages of $(79.6 \%, 80 \%$ and $32.1 \%$ ) respectively [5].

The health and survival of the neonate largely depends on the quality of care both at health facility and in the community available during pregnancy, delivery and post-partum period including the care given to the neonate by the mother or care giver at home. Since 2010 a lot of effort has been put by the Ministry of Health and Child Care (MOHCC) across all the pillars of the health delivery system: Human resources for health, Health financing, Governance and leadership which include coordination and policy setting, Health service delivery, Information surveillance and research and Access to essential drugs and supplies to try and improve newborn outcomes.

The MOHCC adopted new policies aimed at promoting equitable access and utilization of health services by mothers and their newborn at health facilities. User fees were removed in rural health facilities through the Results Based Financing (RBF) and Health Transition Funds (HTF) programmes. The postnatal length of stay at the health facility was increased from $24 \mathrm{hrs}$ to $72 \mathrm{hours}$ as a way of increasing monitoring time by skilled service providers of the mother and newborn during the first critical 72 hours of the newborn.

In the community, MOHCC has revived the village health worker programme (VHW) and the VHWs have been trained to provide health education, health promotional services such as conducting home visits to mothers and their newly born babies during the pregnancy period up to day seven after

A. Munodawafa, Africa University, Zimbabwe.

(e-mail: mutseyekwaf@africau.edu).

F. Mukora-Mutseyekwa, Africa University, Zimbabwe. 
delivery as a way of promoting adoption of key household practices that support the health and survival of the neonate.

Majority of the deaths in the first month of life occur at home where very few of the mothers and care givers are able to recognize signs of newborn illness and the first delay that is the delay in making decisions to seek care for the neonate at the health facility has been identified as the cause for severe morbidity and mortality in the neonates6. According to MICS (2014) care seeking for fever for children under the age of five was $43.6 \%$. This is a cause for concern considering that fever is the main presenting symptoms for the majority of infections and danger signs in the neonates.

The ability to identify that the newborn has a danger sign and the health seeking behaviour for neonatal illness by mothers highly relies on the mother knowledge about neonatal danger signs. In the MICS study, very few mothers/care givers of children under5 years were able to recognize fast or difficult breathing as signs for seeking care immediately. Below is a table indicating the knowledge level of women aged 15-49 years who are mothers or primary caregivers of children under age 5 by symptoms that would cause them to take a child under age 5 immediately to a health facility, and percentage of mothers who recognize fast or difficult breathing as signs for seeking care immediately in Manicaland compared to the national coverage [5].

TABle 1: PERCENTAge OF CAREgIVERS WHO THINK THAT A CHILD SHOUlD \begin{tabular}{|c|c|c|c|c|c|}
\hline \multicolumn{1}{|c|}{ BE TAKEN IMMEDIATELY TO A HEALTH FACILITY } \\
\begin{tabular}{|c|c|c|c|} 
If child is \\
not able to \\
drink or \\
breastfeed
\end{tabular} & $\begin{array}{c}\text { If child } \\
\text { becomes } \\
\text { sicker }\end{array}$ & $\begin{array}{c}\text { If child } \\
\text { has fast } \\
\text { breathing }\end{array}$ & $\begin{array}{c}\text { Has } \\
\text { difficulty } \\
\text { breathing }\end{array}$ & $\begin{array}{c}\text { givers who } \\
\text { knew 2 } \\
\text { pneumonia } \\
\text { danger } \\
\text { signs }\end{array}$ \\
\hline National & 15.2 & 26.6 & 5.3 & 10.3 & 13.0 \\
\hline Manicaland & 10.5 & 15.6 & 2.6 & 9.3 & 11.7 \\
\hline
\end{tabular}

Considering the fact that most neonatal deaths occur at home unattended by skilled health professional, it becomes very important that mothers / care givers of neonates be knowledgeable about the possible danger signs in the neonate and good care of the newborn to avoid mortality related to the first delay.

According to the World Health Organisation (WHO) guidelines, essential newborn care includes hygiene during delivery, keeping the newborn warm, early initiation of breast-feeding, exclusive breast-feeding, care of the eyes, and care during illness, immunisation and care of low birthweight new born babies [7]. The quality of care both at health facility and in the community available during pregnancy, delivery and postpartum period has much impact on immediate recognition of danger signs in the neonate during birth and postpartum period as a result, it is necessary for the mother and family to understand these aspects of childbirth and newborn care and be prepared to react to the potential dangers signs such as hypothermia, jaundice, unable to feed, apnoea, bleeding through the umbilicus, convulsions, and fever [7].

Improving knowledge of newborn care and identification of danger signs in the newborn by mothers of new born babies are strategies which can improve utilization of skilled care and reduction of neonatal mortality in the community. This study sought to determine community and individual factors associated with the practice of the recommended newborn care practices by women of child bearing age in rural and urban communities of Mutare District, Manicaland. The conceptual framework below was used to guide the study.

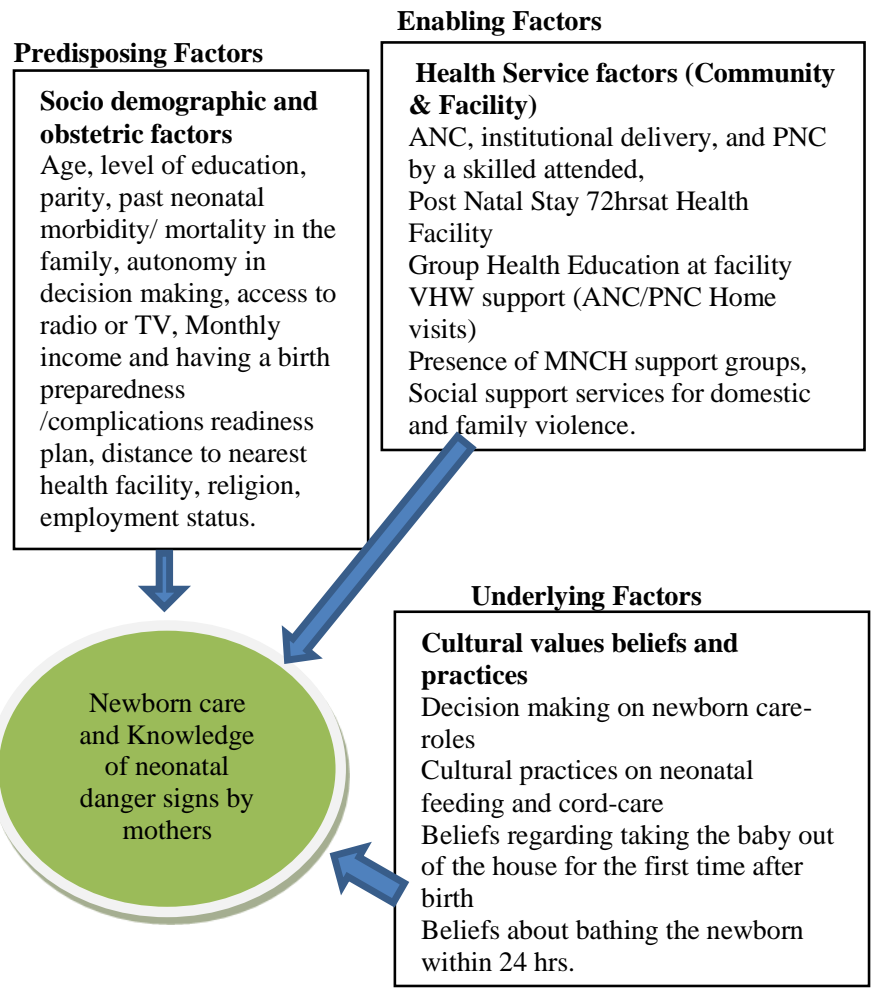

Figure 1: Conceptual Framework for Newborn Care Adapted: Andersen, 1968 and UNICEF, 2009.

\section{METHOD}

An analytical cross-sectional study was conducted among women of child bearing age who delivered a live baby or attended PNC at selected health facilities in Mutare District of Manicaland Province. The study was carried out in catchment areas of six MNH high volume health facilities of Mutare District in Manicaland Province. Mutare district comprises Mutare Urban and Rural. Rural health facilities that were selected based on 2015 District Health Information System 2 (DHIS 2) included: Marange Rural Hospital, Zimunya Clinic and Odzi Clinic. Urban health facilities were Chikanga, Sakubva Poly Clinic and Dangamvura Poly Clinic. The primary study population comprised women of child bearing age who delivered a live baby or attended PNC clinics in the 3 months preceding the data collection period at the selected health facilities.

Six primary health facilities were purposively selected, 3 from the urban community and 3 from the rural community of Mutare District in Manicaland Province. Selection of the facilities was based on the District Health Information System 2 (DHIS 2) reported volume of MNH services that were offered in 2015. Referral centers like Sakubva District Hospital and Mutare Provincial Hospital were excluded from the study. Statistics for postnatal care at 6weeks during the 2015-year period were used as an indicator to select the highvolume sites. Rural health facilities that were selected included: Marange Rural Hospital, Zimunya Clinic and Odzi 
Clinic. Urban health facilities were Chikanga, Sakubva Poly Clinic and Dangamuura Poly Clinic.

All women of child bearing age who delivered a live baby or attended PNC clinics at the selected health facilities during the three-month period preceding the data collection were included in the sampling frame and approached for enrolment into the study.

Manicaland province is among the top two malaria high burdened provinces in Zimbabwe. Considering that fever is the most prevalent symptom for children under the age of five, the study used care seeking for fever as a proxy measure for 'general care seeking for childhood including neonatal illness' and for 'knowledge of newborn danger signs. The prevalence for care seeking during fever in children under the age of 5 years in Manicaland province is 51 percent5. Taking 0.05 as the margin of error at $95 \%$ Confidence Interval (CI) to calculate the sample size, a total of 382 participants will be interviewed. The calculation is as shown below:

Formula used:

$$
n=\frac{z^{2} p q}{d^{2}}
$$

where $n$ - sample size

$Z$ - reliability coefficient

$p-$ population proportion $=51 \%$

$q=(1-p)$

$d$ - width or coefficient limit

$$
\begin{gathered}
n=\left(1.96^{2}(0.51 \times 0.49)\right) / 0.05 \\
n=(3.816 \times 0.25) / 0.0025 \\
n=381.6 \\
n=382
\end{gathered}
$$

Assuming a non-response rate of $10 \%$, the sample size will be 421 participants.

Two stage sampling method was used. The first stage was purposive sampling of health facilities based on the 2015 DHIS2 reported MNH statistics (delivery and PNC data reported in 2015) and the second stage was the systematic random sampling of the participants at each health facility. Six high volume sites were selected, 3 from the Mutare City Health (Chikanga, Sakubva and Dangamvura Health facilities) and 3 from the Mutare Rural District namely Marange, Odzi and Zimunya health facilities. Population sample was proportionally distributed between the six selected health facilities.

The second stage comprised the selection of the primary participants. Listing of all women delivered or who attended PNC clinics in the three months preceding the data collection at the selected clinics was done to develop sampling frames for the different selected clinics. Systematic random sampling method was used to select the participants with no replacement. The first subject was randomly selected from the total population. Based on the required sample, a sampling interval was determined using the formula $\mathrm{k}=\mathrm{N} / \mathrm{n}$ where $\mathrm{k}$, is the sampling interval (skip interval), $\mathrm{N}$ is the total population in the sampling frame for a selected health facility and $\mathrm{n}$ is the required sample size for each health facility.

A structured questionnaire was used to gather data that answered the research questions. This was administered in the form of face to face interviews. Information was collected on the following independent variables:

- Socio demographic factors and Obstetric factors-Age, religion, marital status, parity, level of education, occupation/employment status and area of residence.

- Cultural factors-values ,beliefs and practices about place of delivery, time of initiating $\mathrm{BF}$, feeding practices, bathing the baby, care of the umbilical cord, when to seek care when baby is ill, who makes the decision to seek care for neonatal illness, when to go out after delivery of the newborn, community support systems.

The outcome variables for newborn care practices will include, care seeking for neonatal illness with $24 \mathrm{hrs}$ of onset of fever, keeping baby warm, good cord care explained as keeping the cord stump dry and not applying anything on the cord stump, early initiation of breastfeeding explained as initiating breast feeding within the first hour after delivery, exclusive breast feeding explained as giving breast milk only to the baby for the first six months after birth and bathing the baby after 48 hours.

Pretesting of the data collection instruments was done at Fen valley and Rowa health facilities (Mutare city and Mutare rural respectively). These health facilities have similar characteristics with the selected health facilities. The Data collection tool was shared with peers and supervisors and their feedback was considered to modify the tool as necessary.

Data was collected at each of the selected health facility independently. Face to face interviews were conducted at the health facilities using a structured questionnaire. At the end of each data collection day, the questionnaires were checked for accuracy and consistency. Questionnaires with inaccurate and inconsistent information were rejected and completed questionnaires were kept under lock and key to protect respondent confidentiality.

Data was collected, entered into a data base and analyzed using Epi-Info version 7.2 Descriptive analysis was done in terms of frequency, proportions and mean. Bivariate analysis was performed to assess associations of each of the independent variables with the explanatory variables. Multiple logistic regression models were developed for multivariate analysis to identify independent factors that were associated with good neonatal care and knowledge of newborn danger signs.

Consent to carry out the study was sought from Africa University, Manicaland Provincial Medical Director and the District Medical Officer of Mutare district. Ethical approval was sought from the Africa University Research Ethics Committee. Participants were asked to provide written informed consent before the interview. All pregnant women under the age of 18 years are considered to be young mothers so consented on their own. Confidentiality of information was maintained throughout the study. Names and other identifying information were no required from the participant and questionnaires were coded. Participation was voluntary and respondents were allowed to withdraw from the study at any time to maintain privacy, interviews were conducted individually respecting the respondent's right to privacy. 


\section{RESUlts AND ANALYSIS}

Results displayed in Table 2 show that the majority of the study participants $(31.2 \%)$ were aged $30-40$ years and the median age was 26 years $(\mathrm{Q} 1=22, \mathrm{Q} 3=31)$. Eighty percent of the study participants had reached secondary and higher level of education while $95 \%$ were married and $61 \%$ were residing in the urban area.

TABLE 2: SOCIO-DEMOGRAPHIC INFORMATION OF THE STUDY PARTICIPANTS

\begin{tabular}{|c|c|}
\hline Characteristic $N=349$ & $\begin{array}{c}\text { Frequency } \\
n=(\%)\end{array}$ \\
\hline $\begin{array}{c}\text { Age group in years } \\
16-19 \\
20-24 \\
25-30 \\
31-40 \\
41+ \\
\text { Median age }(\mathbf{Q} 1 ; \mathbf{Q 3})=26(22 ; 31) \\
\end{array}$ & $\begin{array}{c}39(11.2) \\
97(27.8) \\
97(27.8) \\
109(31.2) \\
7(2.0)\end{array}$ \\
\hline $\begin{array}{c}\text { Highest level of education } \\
\text { Primary } \\
\text { Secondary and higher } \\
\end{array}$ & $\begin{array}{r}71(20.0) \\
278(80.0) \\
\end{array}$ \\
\hline $\begin{array}{c}\text { Religion } \\
\text { Apostolic Johanne Marange } \\
\text { Other Christian } \\
\text { Islam } \\
\text { Traditional } \\
\text { No religion }\end{array}$ & $\begin{array}{c}80(24.0) \\
241(69.0) \\
8(2.0) \\
8(2.0) \\
11(3.0)\end{array}$ \\
\hline $\begin{array}{c}\text { Marital status } \\
\text { Married } \\
\text { Not married } \\
\end{array}$ & $\begin{array}{c}329(95.0) \\
17(5.0) \\
\end{array}$ \\
\hline $\begin{array}{c}\text { Occupation } \\
\text { Professional in public sector or private } \\
\text { sector } \\
\text { Peasant farmer } \\
\text { House wife/unemployed } \\
\text { Vendor/trader } \\
\end{array}$ & $\begin{array}{c}23(7.0) \\
21(6.0) \\
164(47.0) \\
140(40.0)\end{array}$ \\
\hline $\begin{array}{c}\text { Parity } \\
\text { One } \\
\text { Two to four } \\
\text { Five and above } \\
\end{array}$ & $\begin{array}{c}103(30.0) \\
213(62.0) \\
29(8.0) \\
\end{array}$ \\
\hline $\begin{array}{c}\text { Place of residence } \\
\text { Urban } \\
\text { Rural } \\
\end{array}$ & $\begin{array}{l}213(61.0) \\
135(39.0) \\
\end{array}$ \\
\hline
\end{tabular}

\section{A. Uptake of recommended interventions for improved} newborn care

As illustrated in Figure 2 above, a total of 349 women of child bearing age $(15-49$ years old) were interviewed with regard to various recommended safe motherhood practices such as ANC attendance, delivering in an institution with a skilled birth attended and staying in the health facility for at least 72 hours to promote monitoring of both the mother and baby during the critical 72 hour window period post-delivery. Eighty five percent of the respondents stated that they had four or more ANC visits to the health facility during their last pregnancy and $77.4 \%$ reported that they had delivered at a health facility. The majority of the respondents $90 \%$ mentioned that they received health education on breastfeeding at the health facility. Among the women who were interviewed, only $18.6 \%$ reported that they had stayed at the health facility for post-natal care within the three-day period with their last child and $26,2 \%$ received a post- natal home visit from the VHW. Less than $10 \%$ reported that they had either received health education during post- natal care or belonged to an $\mathrm{MNH}$ support group.

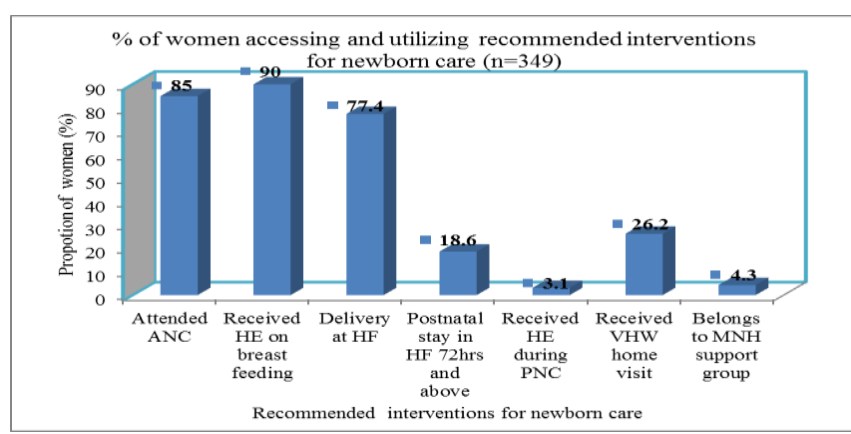

Fig. 2. \% of Women Accessing and Utilizing Recommended Health Interventions for Improved Newborn Care.

\section{B. Uptake of Recommended Newborn Care Practices}

Results displayed in Fig 3 shows that the majority of women $(82 \%)$ practice care seeking for neonatal illness within 24 hours of onset of fever, 74\% initiated breast feeding early, $62 \%$ practiced exclusive breast feeding $58 \%$ bathed their babies after 48 hours after birth while $73 \%$ practiced good cord care.

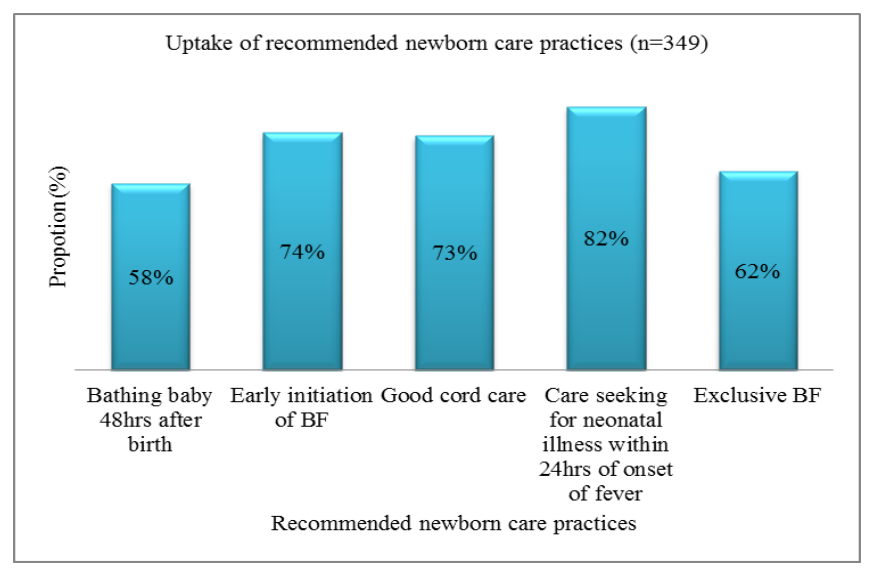

Fig. 3. Uptake of the Recommended New Born Care Practice.

The majority, $31(61 \%)$ of children died between 0 to 6 months as shown in Fig. 4.

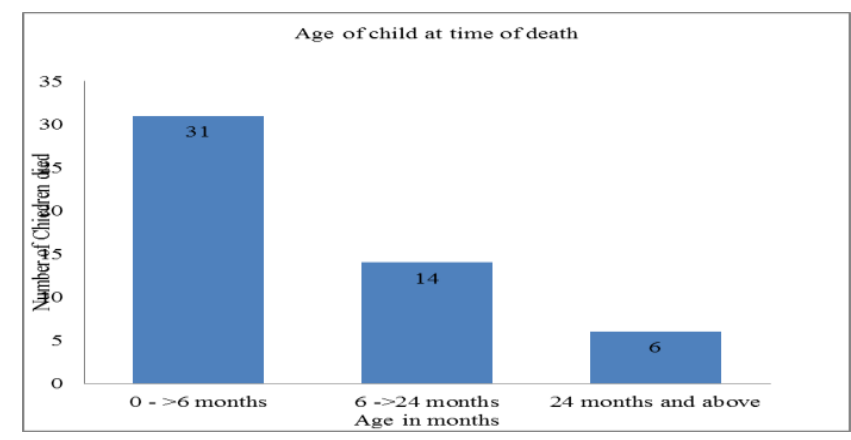

Fig. 4. Age of Child at Time of Death.

\section{Factors associated with newborn care practices among women of child bearing age}

Bivariate analysis was carried out on each of the newborn care practices, crude odds ratios (COR) and their corresponding $95 \%$ confidence intervals (CI) as well as pvalues were presented. Tables 3 to 6 and Figure 5 present the results. 
TABLE 3 EARLY INITIATION OF BF WITHIN ONE HOUR AFTER DELIVERY

\begin{tabular}{|c|c|c|c|c|}
\hline \multirow{2}{*}{ Variable } & \multicolumn{2}{|c|}{$\begin{array}{c}\text { Early initiation of } \\
\text { breast feeding }\end{array}$} & \multirow{2}{*}{$\begin{array}{c}\text { OR } \\
(95 \% \mathrm{CI})\end{array}$} & \multirow{2}{*}{$\begin{array}{c}\mathrm{p}- \\
\text { value }\end{array}$} \\
\hline & Yes n $(\%)$ & $\begin{array}{c}\text { No } \\
\text { n (\%) }\end{array}$ & & \\
\hline $\begin{array}{l}\text { Level of education } \\
\text { Primary } \\
\text { Secondary and } \\
\text { above }\end{array}$ & $\begin{array}{l}38(11.1) \\
33(9.6)\end{array}$ & $\begin{array}{l}165(48.3) \\
106(31.0)\end{array}$ & $\begin{array}{c}0.74 \\
(0.44-1.25)\end{array}$ & 0.167 \\
\hline $\begin{array}{l}\text { Religion } \\
\text { Apostolic } \\
\text { Other } \\
\end{array}$ & $\begin{array}{c}29(8.5) \\
(67.7)\end{array}$ & $\begin{array}{c}49(14.4) \\
32(9.4)\end{array}$ & $\begin{array}{c}0.08 \\
(0.04-0.15) \\
\end{array}$ & $0.000 *$ \\
\hline $\begin{array}{l}\text { Place of residence } \\
\text { Rural } \\
\text { Urban }\end{array}$ & $\begin{array}{l}157(46.2) \\
102(30.0)\end{array}$ & $\begin{array}{c}53(15.6) \\
28(8.2)\end{array}$ & $\begin{array}{c}0.73 \\
(0.41-1.28)\end{array}$ & 0.299 \\
\hline $\begin{array}{l}\text { Received ANC } \\
\text { services } \\
\text { Yes } \\
\text { No }\end{array}$ & $\begin{array}{c}250(73.7) \\
8(2.4)\end{array}$ & $\begin{array}{l}40(11.8) \\
41(12.1)\end{array}$ & $\begin{array}{c}32.03 \\
(13.22-80.35)\end{array}$ & $0.003 *$ \\
\hline $\begin{array}{l}\text { Received health } \\
\text { education on } \\
\text { breast feeding } \\
\text { Yes } \\
\text { No } \\
\end{array}$ & $\begin{array}{c}235(78.6) \\
19(6.3) \\
\end{array}$ & $\begin{array}{c}37(12.4) \\
8(2.7) \\
\end{array}$ & $\begin{array}{c}2.67 \\
(0.99-7.06)\end{array}$ & 0.993 \\
\hline $\begin{array}{l}\text { Place of delivery } \\
\text { Health facility } \\
\text { Home }\end{array}$ & $\begin{array}{c}244(73.5) \\
11(3.3)\end{array}$ & $\begin{array}{l}26(7.8) \\
51(15.4)\end{array}$ & $\begin{array}{c}43.51 \\
(19.09-101.5)\end{array}$ & $0.001 *$ \\
\hline
\end{tabular}

*- statistically significant variable.

Those who belong to the apostolic sect were less likely to initiate breast feeding within one hour after delivery as compared with those from other religion and the results were statistically significant $(\mathrm{COR}=0.04 ; 95 \% \mathrm{CI}: 0.01-0.10$, $\mathrm{p}=0.000$ ). Women who delivered at a facility were 43.59 times more likely to initiate breast feeding early within one hour after delivery as compared with those who delivered at home and the results were statistically significant $(\mathrm{COR}=$ 43.51; 95\%CI: 19.09 -101.50; $\mathrm{p}=0.001)$. Having received ANC services was significantly associated with early initiation of breast feeding the baby. Those who received ANC services were 23.03 times more likely to initiate breast feeding early as compared those who did not receive ANC services $(\mathrm{COR}=23.03$ : 95\% CI: 13.22-80.35, $\mathrm{p}=0$.

Results displayed in Table 4 shows that those who belong to the Apostolic sect were less likely to practices good cord care as compared with those who were from other religious groups and the results are statistically significant $(\mathrm{COR}=0.02$, 95\%CI: $0.01-0.04, p=0.000)$. Level of education and place of delivery was also statistically significantly associated with practicing good cord care. Those who had a secondary or higher level of education were 43.51 times likely to practice good cord care compared to those who had primary level education $(\mathrm{COR}=43.51 ; \mathrm{Cl}$ : 19.09-101.5; $\mathrm{p}=0.001)$. Again, those who delivered at the facility were 49.22 times more likely to practice good cord care as compared to those who delivered at home $(\mathrm{COR}=49.22$; 95\% CI: $19.46-128.47$, $\mathrm{p}=0.00$ ).

Results displayed in Table 5 shows that being apostolic and living in rural areas were associated with care seeking for neonatal illness within 24 hours of onset of fever. Those who belong to the apostolic sect were 2.07 times more likely to seek care for neonatal illness within 24 hours as compared with those who belong to other religious groups (COR: 2.07; 95\% Cl: 1.25 -9.25; $\mathrm{p}=0.013)$. Distance from nearest $\mathrm{HF}$, autonomy in decision making and knowledge of danger signs were also some of independent variables that had an influence on care seeking for neonatal illness within $24 \mathrm{hrs}$. of onset of
fever.(COR:0.58;95\% Cl:0.33-0.87; p=0.015; COR: 0.69; 95\% Cl:0.24-0.78; $\mathrm{p}=0.002$ and COR: $0.4 ; 95 \% \mathrm{Cl}: 0.06-0.89$; $\mathrm{p}=0.006$ ) respectively.

Those who had knowledge of danger signs were 0.4 times more likely to seek care for neonatal illness within $24 \mathrm{hrs}$. of onset of fever.

TABLE 4: FACTORS INFLUENCING GOOD CORD CARE

\begin{tabular}{|c|c|c|c|c|}
\hline \multirow{2}{*}{ Variable } & \multicolumn{2}{|c|}{ Good cord care } & \multirow{2}{*}{$\begin{array}{c}\text { OR } \\
(95 \% \mathrm{CI})\end{array}$} & \multirow{2}{*}{$\begin{array}{c}\text { p- } \\
\text { value }\end{array}$} \\
\hline & Yes n $(\%)$ & No n $(\%)$ & & \\
\hline $\begin{array}{l}\text { Level of } \\
\text { Education } \\
\text { Secondary and } \\
\text { high level } \\
\quad \text { Primary }\end{array}$ & $\begin{array}{c}244(73.5) \\
11(3.3)\end{array}$ & $\begin{array}{l}26(7.8) \\
51(15.4)\end{array}$ & $\begin{array}{c}43.51 \\
(19.09- \\
101.5)\end{array}$ & $0.001 *$ \\
\hline $\begin{array}{l}\text { Religion } \\
\text { Apostolic } \\
\text { Other }\end{array}$ & $\begin{array}{r}12(4.6) \\
182(70.3)\end{array}$ & $\begin{array}{c}52(20.1) \\
13(5.0)\end{array}$ & $\left(\begin{array}{c}0.02 \\
(0.01-0.04)\end{array}\right.$ & $0.000 *$ \\
\hline $\begin{array}{l}\text { Place of residence } \\
\text { Rural } \\
\text { Urban }\end{array}$ & $\begin{array}{c}74(28.6) \\
120(46.3)\end{array}$ & $\begin{array}{l}27(10.4) \\
38(14.7)\end{array}$ & $\begin{array}{c}0.87 \\
(0.47-1.60)\end{array}$ & 0.364 \\
\hline $\begin{array}{l}\text { Parity } \\
\text { One } \\
\text { More than one }\end{array}$ & $\begin{array}{c}57(22.4) \\
134(52.5)\end{array}$ & $\begin{array}{c}15(5.9) \\
49(19.2)\end{array}$ & $\left(\begin{array}{c}1.39 \\
(0.69-2.83)\end{array}\right.$ & 0.409 \\
\hline $\begin{array}{l}\text { Post-natal stay in } \\
\text { clinic } \\
\text { Less than } 72 \text { hrs } \\
72 \text { hrs and above }\end{array}$ & $\begin{array}{c}120(58.3) \\
61(29.6) \\
\end{array}$ & $\begin{array}{c}21(10.2) \\
4(1.9) \\
\end{array}$ & $\begin{array}{c}0.37 \\
(0.10-1.22)\end{array}$ & 0.120 \\
\hline $\begin{array}{l}\text { Place of delivery } \\
\text { Health facility } \\
\text { Home }\end{array}$ & $\begin{array}{c}179(71.9) \\
10(4.0)\end{array}$ & $\begin{array}{c}16(6.4) \\
44(17.7)\end{array}$ & $\begin{array}{r}49.22 \\
(19.46- \\
128.47)\end{array}$ & $0.000^{*}$ \\
\hline $\begin{array}{l}\text { Post-natal death } \\
\text { in the family } \\
\text { Yes } \\
\text { No }\end{array}$ & $\begin{array}{c}12(31.6) \\
5(13.1) \\
\end{array}$ & $\begin{array}{c}12(31.6) \\
9(23.7) \\
\end{array}$ & $\left(\begin{array}{c}1.80 \\
(0.38-8.71)\end{array}\right.$ & 0.178 \\
\hline $\begin{array}{l}\text { Being assisted } \\
\text { with newborn } \\
\text { care } \\
\text { Yes } \\
\text { No }\end{array}$ & $\begin{array}{c}100(39.2) \\
90(35.3)\end{array}$ & $\begin{array}{c}59(23.1) \\
6(2.4)\end{array}$ & $\left(\begin{array}{c}0.93 \\
(0.11-7.93)\end{array}\right.$ & 0.686 \\
\hline
\end{tabular}

*- statistically significant variable

TABLE 5 FACTORS INFLUENCING CARE SEEKING FOR NEONATAL ILLNESS WITHIN 24 HOURS OF ONSET OF FEVER

\begin{tabular}{|c|c|c|c|c|}
\hline \multirow[t]{2}{*}{ Variable } & \multicolumn{2}{|c|}{$\begin{array}{l}\text { Care seeking for neonatal } \\
\text { illness within } 24 \text { hrs of onset } \\
\text { of fever }\end{array}$} & \multirow{2}{*}{$\begin{array}{l}\text { OR }(95 \% \\
\text { CI })\end{array}$} & \multirow{2}{*}{$\begin{array}{c}\mathrm{p}- \\
\text { value }\end{array}$} \\
\hline & Yes n $(\%)$ & $\begin{array}{c}\text { No } \\
\text { n (\%) }\end{array}$ & & \\
\hline $\begin{array}{l}\text { Religion } \\
\text { Apostolic } \\
\text { Other } \\
\end{array}$ & $\begin{array}{c}72(21.8) \\
215(65.1) \\
\end{array}$ & $\begin{array}{c}6(1,8) \\
37(11.2) \\
\end{array}$ & $\begin{array}{c}2.07 \\
(1.25-9.27)\end{array}$ & $0.013^{*}$ \\
\hline $\begin{array}{l}\text { Place of residence } \\
\text { Rural } \\
\text { Urban }\end{array}$ & $\begin{array}{l}179(54.2) \\
107(32.4) \\
\end{array}$ & $\begin{array}{l}22(6.7) \\
22(6.7) \\
\end{array}$ & $\begin{array}{c}1.67 \\
1.12-10.89)\end{array}$ & $0.002 *$ \\
\hline $\begin{array}{l}\text { Distance from nearest } \\
\text { health facility } \\
\text { Less than } 10 \mathrm{KM} \\
+10 \mathrm{KM}\end{array}$ & $\begin{array}{c}276(83.4) \\
11(3.3) \\
\end{array}$ & $\begin{array}{c}43(13.0) \\
1(0.3) \\
\end{array}$ & $\begin{array}{c}0.58 \\
(0.33-0.87)\end{array}$ & $0.015^{*}$ \\
\hline $\begin{array}{l}\text { Autonomy in decision } \\
\text { making } \\
\text { Self } \\
\text { Husband/in-laws }\end{array}$ & $\begin{array}{c}172(60.6) \\
72(25.4)\end{array}$ & $\begin{array}{c}31(10.9) \\
9(3.2)\end{array}$ & $\begin{array}{c}0.69 \\
(0.24-0.78)\end{array}$ & $0.002 *$ \\
\hline $\begin{array}{l}\text { Level of education } \\
\text { Primary } \\
\text { Secondary and } \\
\text { above }\end{array}$ & $\begin{array}{r}61(18.4) \\
226(68.3) \\
\end{array}$ & $\begin{array}{c}8(2.4) \\
36(10.9) \\
\end{array}$ & $\begin{array}{c}1.21 \\
(0.23-9.78)\end{array}$ & 0.121 \\
\hline $\begin{array}{l}\text { Post-natal death in } \\
\text { the family } \\
\text { Yes } \\
\text { No }\end{array}$ & $\begin{array}{c}42(12.8) \\
243(73.9)\end{array}$ & $\begin{array}{c}4(1.2) \\
40(12.1) \\
\end{array}$ & $\begin{array}{c}1.73 \\
0.76-11.76)\end{array}$ & 0.345 \\
\hline $\begin{array}{l}\text { Knowledge of } \\
\text { newborn danger signs } \\
\text { Yes } \\
\text { No }\end{array}$ & $\begin{array}{c}7(14.6) \\
35(72.9) \\
\end{array}$ & $\begin{array}{l}2(4.2) \\
4(8.3) \\
\end{array}$ & $\begin{array}{c}0.4 \\
(0.06-0.89)\end{array}$ & $0.006^{*}$ \\
\hline
\end{tabular}

*- statistically significant variable 
Results presented in Table 6 shows that statistically significant factors associated with exclusive breast feeding were being apostolic and having attained primary as the highest level of education. Those who were from the apostolic sect and those with primary level of education as their highest level were less likely to breast feed exclusively $(\mathrm{COR}=0.27 ; 95 \% \mathrm{CI}: 0.15-0.47 ; \mathrm{p}=0.000)$ and $(\mathrm{COR}=0.35$; 95\%CI: $0.20-0.63 ; \mathrm{p}=0.000)$ respectively.

TABLE 6: FACTORS Associated With ExCLUSIVE BREAST FEEDING

\begin{tabular}{|c|c|c|c|c|}
\hline \multicolumn{5}{|c|}{ (EBF) } \\
\hline \multirow[b]{2}{*}{ Variable } & \multicolumn{2}{|c|}{$\mathrm{EBF}$} & \multirow{2}{*}{$\begin{array}{c}\text { OR } \\
(95 \% \mathrm{CI})\end{array}$} & \multirow[b]{2}{*}{ p-value } \\
\hline & $\begin{array}{c}\text { Yes } \\
\text { n (\%) }\end{array}$ & $\begin{array}{c}\text { No } \\
\text { n (\%) }\end{array}$ & & \\
\hline $\begin{array}{l}\text { Religion } \\
\text { Apostolic } \\
\text { Other }\end{array}$ & $\begin{array}{c}30(8.8) \\
185 \\
(53.9) \\
\end{array}$ & $\begin{array}{c}48(14) \\
80(23.3)\end{array}$ & $\begin{array}{c}0.27 \\
(0.15-0.47)\end{array}$ & $0.000 *$ \\
\hline $\begin{array}{l}\text { Place of residence } \\
\text { Rural } \\
\text { Urban }\end{array}$ & $\begin{array}{c}136(41.0) \\
79(23.3) \\
\end{array}$ & $\begin{array}{l}70(20.7) \\
54(15.9) \\
\end{array}$ & $\begin{array}{c}1.33 \\
(0.83-2.14)\end{array}$ & 0.263 \\
\hline $\begin{array}{l}\text { Parity } \\
\text { One } \\
\text { More than one }\end{array}$ & $\begin{array}{c}144(42.4) \\
69(22.3) \\
\end{array}$ & $\begin{array}{c}96(28.2) \\
31(9.1) \\
\end{array}$ & $\begin{array}{c}0.64 \\
(0.40-1.14)\end{array}$ & 0.150 \\
\hline $\begin{array}{l}\text { Autonomy in } \\
\text { decision making } \\
\text { Self } \\
\text { Husband/in-laws }\end{array}$ & $\begin{array}{c}159(54.1) \\
53(18.0)\end{array}$ & $\begin{array}{c}53(18.0) \\
29(9.9) \\
\end{array}$ & $\begin{array}{c}1.64 \\
(0.91-2.95)\end{array}$ & 0.103 \\
\hline $\begin{array}{l}\text { Level of education } \\
\text { Primary } \\
\text { Secondary and } \\
\text { above }\end{array}$ & $\begin{array}{c}30(8.7) \\
186(54.1) \\
\end{array}$ & $\begin{array}{l}40(11.6) \\
88(25.6) \\
\end{array}$ & $\begin{array}{c}0.35 \\
(0.20-0.63)\end{array}$ & $0.000 *$ \\
\hline $\begin{array}{l}\text { Belongs to } M N H \\
\text { support groups } \\
\text { Yes } \\
\text { No }\end{array}$ & $\begin{array}{c}12(3.6) \\
194(58.6)\end{array}$ & $\begin{array}{c}2(0.6) \\
123(37.2)\end{array}$ & $\begin{array}{c}4.31 \\
(0.95-19.61)\end{array}$ & 0.133 \\
\hline $\begin{array}{l}\text { Post-natal death } \\
\text { in the family } \\
\text { Yes } \\
\text { No }\end{array}$ & $\begin{array}{c}26(7.6) \\
189(55.1)\end{array}$ & $\begin{array}{c}25(7.3) \\
103(30.0)\end{array}$ & $\begin{array}{c}1.51 \\
(0.82-2.78)\end{array}$ & 0.121 \\
\hline $\begin{array}{l}\text { VHW PNC home } \\
\text { visits } \\
\text { Yes } \\
\text { No }\end{array}$ & $\begin{array}{c}28(8.4) \\
105(31.6)\end{array}$ & $\begin{array}{c}59(17.8) \\
14041.2) \\
\end{array}$ & $\begin{array}{c}0.63 \\
(0.38-1.06)\end{array}$ & 0.052 \\
\hline $\begin{array}{l}\text { Received health } \\
\text { education after } \\
\text { delivery } \\
\text { Yes } \\
\text { No }\end{array}$ & $\begin{array}{c}5(2.3) \\
161(72.5) \\
\end{array}$ & $\begin{array}{c}2(0.9) \\
54(23.4) \\
\end{array}$ & $\begin{array}{c}0.84 \\
(0.1-6.44)\end{array}$ & 0.564 \\
\hline
\end{tabular}

*- statistically significant variable.

\section{Factors associated with keeping the baby warm soon after delivery}

At least $59 \%$ of the participants interviewed bathed their babies 48 hours after delivery. Multivariate analysis was done to allow for efficient estimation of measures of association between independent factors and newborn care practices while controlling for a number of confounding variables simultaneously. Stepwise logistic regression analysis is the technique that was used in multivariate analysis. Adjusted

Odds Ratios (AOR) and their corresponding p-values and 95\% confidence intervals (CI) were calculated. Table 7 below shows final results of stepwise logistic regression analysis.

Results displayed in Table 7 shows that statistically significant independent factors associated with the recommended newborn care practices were post-natal stay for more than 72 hours at the clinic $(\mathrm{AOR}=0.56$; 95\%CI: 0.12 $0.87, \mathrm{p}=0.000)$, and delivery at the health facility $(\mathrm{AOR}=0.43 ; 95 \% \mathrm{CI}: 0.21-0.77 ; \mathrm{p}=0.000)$.
TABLE 7: INDEPENDENT FACTORS ASSOCIATED With NEWBORN CARE PRACTICES

\begin{tabular}{|l|c|c|c|}
\hline \multicolumn{1}{|c|}{ Factor } & AOR & $95 \%$ CI & $\begin{array}{c}\text { p- } \\
\text { value }\end{array}$ \\
\hline Belonging to the Apostolic sect & 3.25 & $1.56-10.46$ & $0.001^{*}$ \\
\hline $\begin{array}{l}\text { Received health education during } \\
\text { ANC visits }\end{array}$ & 0.07 & $0.01-1.28$ & 0.141 \\
\hline $\begin{array}{l}\text { Post-natal stay for more than 72 } \\
\text { hours at clinic }\end{array}$ & 0.56 & $0.12-0.87$ & $0.000^{*}$ \\
\hline Delivery at health facility & 0.43 & $0.21-0.77$ & $0.000^{*}$ \\
\hline $\begin{array}{l}\text { Received health education on breast } \\
\text { feeding }\end{array}$ & 0.12 & $0.01-2.31$ & 0.465 \\
\hline $\begin{array}{l}\text { Having a post-natal death in the } \\
\text { family }\end{array}$ & 0.78 & $0.25-3.66$ & 0.762 \\
\hline Knowledge of newborn danger signs & 0.79 & $0.33-1.67$ & 0.537 \\
\hline
\end{tabular}

*-statistically significant variable.

\section{E. Cultural values and belief that impact on neonatal care}

The cultural values and beliefs which were assessed were whether women first seek permission for the child to be treated if the child is ill and the beliefs related to taking the newborn outside the house or home environment in the first week of life. The results revealed that $60 \%$ of the study participants seek permission for treating their children when the child is ill while $40 \%$ responded that they do not seek any permission from anyone. Majority of the participants $(81 \%)$ indicated that they seek permission from the husband.

\section{F. Cultural practices}

The commonest first feeds given immediately to newborns after delivery were water, porridge mixed with herbs and cooking oil.

A large proportion of the participants $40.6 \%$ indicated that they gave the baby an early bath within $48 \mathrm{hrs}$ after birth in compliance with their local culture. Some of the cultural practices which are being used for caring for the cord stump of a newly born baby include the use of ashes which was applied by 11 of the study participants; cow dung was also being used by 2 of the women while 51 women used mixed traditional herbs as a way of caring for the cord stump of the baby. Figure 5 below shows the time taken to take the newborn outside the house.

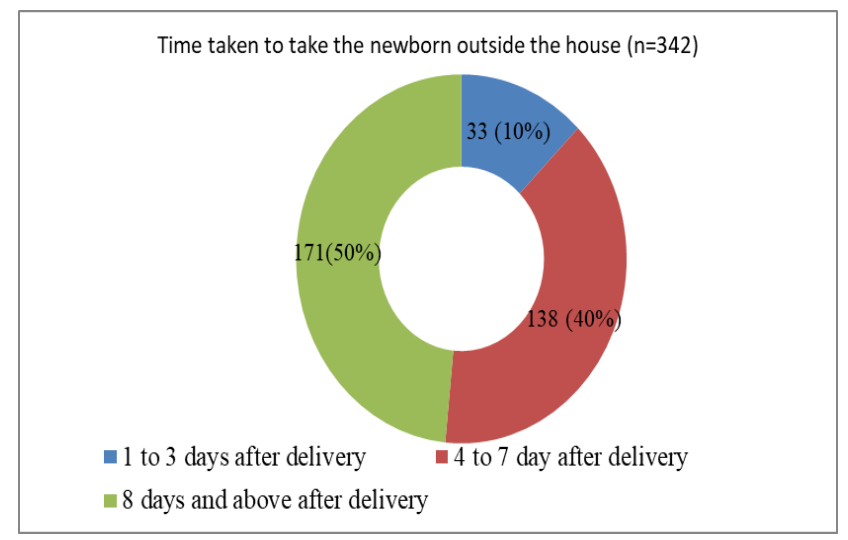

Fig. 5. Time Taken to Take The Newborn Outside the House.

The cultural practice and beliefs regarding when to take the newborn outside the house or home environment revealed that $50 \%$ of the participants delayed taking the baby outside the house/home environment. The study also explored the reasons for the delay in taking the baby out, majority 92 
$(54 \%)$ of those who delayed indicated that the umbilical cord stump had not yet dried so they wanted to protect the baby from evil spirits. Seventy-seven (45\%) reported that they delayed because culturally the newborn should not be exposed to the sun in the first month, $2(1 \%)$ of the participants reported that they delayed taking the baby outside the house/ home environment because the mother was ill.

\section{DISCUSSION}

Age of the mother, level of education, parity, religion and distance from the nearest health facility are some of the sociodemographic factors that have been cited in various studies to be predictors of the care provided to the newborn by the mother when at home [8][9][10][11]. Despite the proportion of teenage mothers in the study being a bit lower compared to the ZDHS (2015/16), teenage pregnancy and motherhood is a major social and health concern. Teenage mothers are more likely to suffer from severe complications during delivery, which may result in high morbidity and mortality for both the mother and the child. In addition, they may not be sufficiently mature and prepared for childbearing and child care. Childbearing at an early age greatly reduces women's educational potential and employment opportunities and is associated with higher levels of fertility [12]. These factors may have negative impacts on their job prospects, their status in society and consequently their newborn caring practices. The age of the woman influenced the knowledge of and attitude towards antenatal care [13]. The young and adolescent mothers were more likely to lack knowledge and support and were more likely to face domestic and family violence, gender, economic and health service problems linked to the pregnancy. These problems traumatize and stigmatize the young girls and constrained their options for social and medical support for pregnancy and neonatal care. Emotional, physical and sexual violence was more pronounced in women aged 15-19 than in any other age groups in Zimbabwe [5].

The study results showed that about eighty percent of the study participants had reached secondary and higher level of education which might mean that these women are highly literate. Mutare district is one of the seven districts in Manicaland province thus the above figures give an indication that Manicaland has a highly educated and literate community. A higher level of education can be inferred to be a proxy indicator for independence and autonomy in decision making. Accordingly, autonomy in decision making is a strong predictor of good newborn practices.

There was an association between the level of education and exclusive breast feeding with participants who had a secondary or higher level of education being 0.65 times more likely to exclusively breast feed than those who had primary level education. Women who had secondary or high-level education were 43.2 times more likely to practice the recommended cord care practice than those who had primary level education. Consistent with the above findings is the evidence from Tanzania National Demographic Health Survey which revealed that $58 \%$ of children born to mothers with some secondary education started breastfeeding within one hour of birth.
In contrast to the above statements, this study revealed that high level of education was not a predictor of care seeking for neonatal illness within 24 hours of onset of fever (COR:1.21; 95\% Cl: 0.23-9.78) and early initiation of breastfeeding in the first hour after delivery(COR:0.74; $95 \%$ $\mathrm{Cl}: 0.44-1.25 ; \mathrm{p}=0.167)$. This is consistent with the findings of an unpublished study done by Hara (2011) in Malawi which found no significant association between knowledge level of newborn danger signs and the educational level of the mother.

Lack of significant association between maternal education and good neonatal feeding practices and knowledge of specific newborn danger signs was also noted in Ethiopia14.

In this study, a total of $208(60.8 \%)$ were from rural areas and $133(38.9 \%)$ were from the urban areas. The place of residence was not associated with the recommended newborn care practices: bathing the baby after the first 48 hours after delivery; early initiation of breast feeding within the first hour after delivery; good cord care and exclusive breast feeding for at least 4 to 6 months. Living in rural areas was associated with care seeking for neonatal illness within 24 hours of onset of fever. This is contrary to findings from other studies done by Shirima and others and Fenn and others which revealed that essential newborn care practices were inadequate in rural communities more than in urban areas [16][17]. A possible explanation to the lack of association between place of residence and other newborn care practices: bathing the baby after the first 48hours after delivery; early initiation of breast feeding within the first hour after delivery; good cord care and exclusive breast feeding for at least 4 to 6 months may be that the population studied was relatively homogenous thus absolute differences were generally not significant between those who stayed in urban and rural areas.

Some of the cultural practices that were noted in this study to impact negatively on newborn in Mutare district were that mothers in the study were asking for permission from someone to seek treatment for the child when ill, giving the newborn an early bath with 48 hours after birth, feeding the baby immediately after delivery with either water, porridge with mixed herbs as well as giving babies cooking oil; using ashes, cow dung as well as applying mixed traditional herbs as a way of caring for the cord stump of the newly born baby and also delaying taking the baby outside the house or home environment until after one week after delivery. Results from this study also showed that besides going to the health facility to seek treatment, women also visit the herbalists some visit prophets while some were using holy water as other means of treating the child whenever they fell ill.

Mothers in Manicaland province still seek permission from husbands to seek treatment. This reflects the patriarchal culture in which the concepts of machismo portray the masculine figure as a protector, provider and decision maker, the woman then is expected to defer important decisions to and sometimes communicate through the male figure. This culturally ascribed male dominance, superiority, honor, and respect coupled with the limited capacity of the women to mobilize financial resources due to poor education often times disempower or stripes down the decision making autonomy of the mother to comply with the recommended good newborn care practices and may exacerbate the first delay in seeking care that is delay in making the decision to 
seek care for newborn illness.

Bathing of the baby within 48 hours after delivery is one of the care practices that negatively impacts on the newborn`s health and is usually culturally driven. In this study $40.6 \%$ of the mothers reported giving the baby an early bath after delivery. This is too big a proportion of mothers who are exposing the newborn to the risk of hypothermia. The need to bath the baby very early soon after birth stems from the cultural beliefs that the birth process is a ritually impure and a polluting process from which cleansing is needed and the cultural belief that babies should be bathed to remove vernix, if vernix is not removed the newborn would suffer from boils and ills [18]. Saaka and Iddrisu, noted that bathing of the newborn within the first hour after delivery was usually done by relatives such as the aunts and grandmothers and widely prevalent because the baby`s body is usually covered with vernix which is considered to be dirty [18]. In Uganda early bathing was practiced because of the cultural belief that babies are born dirty therefore bathing the baby soon after birth is a way of purifying the baby [9].Early bathing of the baby tend to quicken the removal of the lipid rich vernix. Vernix has many functions which include enhancing the epidermal barrier function and development, protecting the skin, optimizing hydration, minimizing transdermal water loss, protecting the skin from trauma, hypothermia and infection.

Giving of prelacteal feeds is one of the cultural practices that have been noted to expose the newborn to infections. MOHCC in Zimbabwe recommends exclusive breast feeding of the newborn baby for a period of six months. In this study a relatively small number of mothers 33 (9.5\%) gave prelacteal feeds to the newborn

Some studies have revealed that cultural practices encouraged mothers to give prelacteal feeds. Sreeramareddy and other identified that $53 \%$ of mothers gave home remedies for digestion4. In addition, Sethi noted that TBAs encouraged mothers to give other feeds like honey, ghutti and water to the newborn since these were perceived to have health benefits of reducing colic or acting as laxative [19]. All these practices and belief expose the newborn to infections

In the home environment, cultural and traditional values, beliefs and practices to which a family belongs play a very important role in influencing the mother's thinking about neonatal health and illness, health practices and the care given to the newborn as well as care seeking behaviours for neonatal illness in the community [20]. According to the WHO, the most critical time for the newborn is the first week of life. To reduce morbidity and mortality in this critical time, in Zimbabwe, it is policy that both the mother and newborn be monitored by skilled health care providers in the health facility for the first three days and then to come back to the health facility on day seven for assessment and support. This means that within the first week of life, the baby should be taken out of the house/ home environment to visit the health facility. In our study, $50 \%$ delayed taking the baby outside the house/home environment. The main reasons that was cited by the majority $92(54 \%)$ of participants who delayed taking the baby out of the home environment was the need to protect the baby from evil spirits during the time when the cord stump was still in place 'not dry. Mothers first sought care from traditional and religious healers. This is an indication that cultural value systems expose women to barriers that lie beyond lack of resources in healthcare services or accessibility to such services and without skilled their newborn may be forced to succumb to/exposed to traditional and cultural practices which may be detrimental to the health of the neonate 21 .

\section{CONCLUSION}

This study sought to identify community (cultural factors) and care-giver factors that are associated with maternal and neonatal health outcomes. The study revealed that both demographic factors and cultural/religious factors have a substantial influence on newborn care practices by mothers in Mutare district. The results from this study showed that $15 \%$ of the study participants had ever given birth to a child who was born alive but later died and that the majority, $61 \%$ of the children died between 0 to 6 months. Most of the deaths occurred at home. Independent factors associated with the recommended newborn care practices were having a postnatal stay for more than 72 hours at the clinic, delivery at the health facility, having received health education on breast feeding, having a post-natal death in the family and having knowledge of newborn danger signs.

The study also reveal that the cultural practices which impacted negatively on new born care were feeding the baby immediately after delivery with either water, porridge with mixed herbs as well as giving babies cooking oil. Other cultural practices which had a negative impact on new born care were using ashes, cow dung as well as applying mixed traditional herbs as a way of caring the cord stump of the newly born baby. Results from this study also showed that besides going to the health facility to seek treatment, women were also visiting the herbalists; some visit prophets while some were using holy water as other means of treating the child whenever they fell ill.

There is great need to strengthen the community mobilisation and social behaviour change communication strategy to increase empowerment of care-givers with correct and consistent messages to improve neonatal care practices and improve neonatal health outcomes.

\section{REFERENCES}

[1] J.E. Lawn, S. Cousens, and J. Zupan, "4 million neonatal deaths: when? Where? Why?" Lancet, 365(9462), 891-900, 2005.

[2] Save the Children. State of the world's newborns. Washington, DC: Save the Children. 2000: Retrieved from http://www.savethechildren.org/publications/newborns_report.pdf. 2000.

[3] U. Lehmann, and D. Sanders, "Community health workers - what do we know about them? The state of the evidence on programmes, activities, costs and impact on health outcomes of using community health workers." World Health Organization, 2007.

[4] C. Sreeramareddy, H. Joshi, B. Sreekumaran, S. Giri, N. Chuni, "Home delivery and newborn care practices among urban women in western Nepal: a questionnaire survey". BMC Pregnancy and Childbirth, 6(1), 27, 2006.

[5] Zimbabwe National Statistics Agency (ZIMSTAT). Multiple Indicator Cluster Survey 2014, Final Report. Harare, Zimbabwe, 2014.

[6] J.E., Lawn, S. Cousens, and J. Zupan, "4 million neonatal deaths: When? Where? Why?" Lancet, 365:89" 1-900, 2005.

[7] World Health Organization (WHO). "Maternal and Newborn Health Safe Motherhood Essential Newborn Care Report- A Technical Working Group Trieste", 25-29 April 1994 Geneva. 
[8] P. Waisa, S. Peterson, G. Tomson, and W.G. Pariyo, "Poor newborn care practices - a population based survey in eastern Uganda". Retrieved from Http//www.biomedcentral.com/1471-2393/10/9, 2010

[9] V.O. Kayom, A. Kakuru, and S. Kiguli, "Newborn Care Practices among Mother-Infant Dyads in Urban Uganda", International Journal of Pediatrics Volume 2015, http://dx.doi.org/10.1155/2015/815938, 2015.

[10] R. Ayiasi, M. Criel, B. Orach, C. G. Nabiwemba, and E. Kolsteren. "Primary healthcare worker knowledge related to prenatal and immediate newborn care: a cross sectional study in Masindi, Uganda." BMC Health Services Research, 14:65 doi: 10.1186/1472-6963-14-65, 2014.

[11] A. J. Kersterton, and J. Cleland, "Neonatal care in rural Karnataka: healthy and harmful practices, the potential for change", 2009.

[12] J. DeVito, "How Adolescents Mothers Feel About Becoming a Parent. Journal of Perinatal education", 19(2), 25-34, doi 10.1624/10581210X495523. 2010.

[13] O. Lincetto, S. Mothebesoane-Anoh, P. Gomez, and S.P. Munjanja "Antenatal care-in Opportunities for Africa`s newborns: practical data, policy and programmatic support for newborn care in Africa". Cape Town; 2006.

[14] Y. Workineh, D. Hailu, T. Gultie, N. Degefu, M. Mihrete, M. Shimele, M. Mahino, M. Guesh, and M. Alemu, "Knowledge of Obstetric Danger Signs and its Associated Factors in Arba Minch Town, Ethiopia", American Journal of Health Research, Vol. 2, No. 5, pp. 255-259. doi: 10.11648/j.ajhr.20140205.16, 2014.

[15] R. Shirima, M. Gebre-Medhin, T. and Greiner, "Information and socioeconomic factors associated with early breastfeeding practices in rural and urban Morogoro, Tanzania.” Acta Paediatr 90(8) 936-942, 2001.

[16] B. Fenn, B.R. Kirkwood, Z. Popatia and D.J. Bradly, ".Inequalities in neonatal survival interventions: evidence from national surveys." Arch Dis child Fetal Neonatal ED, 92(5): F 361-366, 2007.

[17] J.A. Kersterton, and J. Cleland, "Neonatal care in rural Karnataka: healthy and harmful practices, the potential for change.", 2009.

[18] M. Saaka, and M. Iddrisu, "Patterns and Determinants of Essential Newborn Care Practices in Rural Areas of Northern Ghana.", Retrievedfrom://www.hindawi.com/journals/ijpr/2014/404387, 2014.

[19] V. Sethi, S. Kashyap and S. Agarwal, "Contextual Factors Influencing Newborn Care Amongst Rural Poor in Western Uttar Pradesh." Pakistan Journal of Nutrition, 4 (4), 273-275, 2005.

[20] Z.K. Reshma, and R. Sujatha, "Cultural practices and beliefs on newborn care among mothers in a selected hospital of Mangalore Taluk.", Nitte University Journal of Health Science: NUJHS Vol. 4, No.2, June 2014

[21] S. Premji, S. Khowaja, S. Meherali, and R. Rachelle Forgeron, "Sociocultural influences on newborn health in the first 6 weeks of life: qualitative study in a fishing village in Karachi, Pakistan." BMC Pregnancy and Childbirth, 14:232, 2014. 